Review Article

\title{
Cannabinoid Effects on Experimental Colorectal Cancer Models Reduce Aberrant Crypt Foci (ACF) and Tumor Volume: A Systematic Review
}

\author{
Eduardo Orrego-González (iD, ${ }^{1}$ Luisa Londoño-Tobón, ${ }^{1}$ José Ardila-González, ${ }^{1}$ \\ Diego Polania-Tovar, ${ }^{1}$ Ana Valencia-Cárdenas, ${ }^{2}$ and Alberto Velez-Van Meerbeke $\mathbb{B}^{1}$ \\ ${ }^{1}$ Research Group, Neurosciences (NEUROS), School of Medicine and Health Sciences, Universidad Del Rosario, Bogotá, Colombia \\ ${ }^{2}$ Hospital Universitario Mayor (MEDERI), Bogotá, Colombia
}

Correspondence should be addressed to Alberto Velez-Van Meerbeke; alberto.velez@urosario.edu.co

Received 21 February 2020; Revised 8 June 2020; Accepted 25 June 2020; Published 20 July 2020

Academic Editor: Francesca Borrelli

Copyright (C) 2020 Eduardo Orrego-González et al. This is an open access article distributed under the Creative Commons Attribution License, which permits unrestricted use, distribution, and reproduction in any medium, provided the original work is properly cited.

\begin{abstract}
Objective. Colorectal cancer represents a heavy burden for health systems worldwide, being the third most common cancer worldwide. Despite the breakthroughs in medicine, current chemotherapeutic options continue to have important side effects and may not be effective in preventing disease progression. Cannabinoids might be substances with possible therapeutic potential for cancer because they can attenuate the side effects of chemotherapy and have antiproliferative and antimetastatic effects. We aim to determine, through a systematic review of experimental studies performed on animal CRC models, if cannabinoids can reduce the formation of preneoplastic lesions (aberrant crypt foci), number, and volume of neoplastic lesions. Materials and Methods. A systematic, qualitative review of the literature was conducted in accordance with Preferred Reporting Items for Systematic Reviews and Meta-Analyses (PRISMA) guidelines. PubMed, Embase, and Scopus databases were searched. We use the following Medical Subject Headings (MESH) terms in PubMed: "colorectal neoplasms," "colonic neoplasms," "colorectal cancer," "polyps," "rimonabant," "cannabidiol," "cannabinoids," "azoxymethane," "xenograft," and "mice." Only studies that met the eligibility criteria were included. Results. Eight in vivo experimental studies were included in the analysis after the full-text evaluation. Seven studies were azoxymethane (AOM) colorectal cancer models, and four studies were xenograft models. Cannabidiol botanical substance (CBD BS) and rimonabant achieved high aberrant crypt foci (ACF) reduction ( $86 \%$ and $75.4 \%$, respectively). Cannabigerol, O-1602, and URB-602 demonstrated a high capacity for tumor volume reduction. Induction of apoptosis, interaction with cell survival, growth pathways, and angiogenesis inhibition were the mechanisms extracted from the studies that explain cannabinoids' actions on CRC. Conclusions. Cannabinoids have incredible potential as antineoplastic agents as experimental models demonstrate that they can reduce tumor volume and ACF formation. It is crucial to conduct more experimental studies to understand the pharmacology of cannabinoids in CRC better.
\end{abstract}

\section{Background}

Colorectal cancer (CRC) is the third most common cancer worldwide, only behind prostate and lung in males, and behind breast and lung in females [1]. It has high morbidity and mortality that represents a heavy burden for health systems worldwide. In the United States alone, with roughly 1.8 million new cases in 2018 , healthcare costs exceed $\$ 14$ billion annually [2]. In addition, it is the fourth cause of cancer-related deaths $[3,4]$. CRC represents a significant public health concern because temporal projections estimate that its global burden will increase by $60 \%$ to more than 2.2 million new cases and 1.1 million cancer deaths by 2030 [5].

CRC is a type of cancer with a complex and heterogeneous pathophysiology. It is the result of the transformation of healthy colonic epithelial cells into cancer [6]. This process, called "adenoma-carcinoma sequence," develops through an ordered series of events, in which the initial step 
is the transformation of normal colonic epithelium to aberrant crypt foci (ACF) [6]. ACF progress to CRC, in 10-15 years [7]. During this process, many risk factors play an essential role in pathogenesis, including unhealthy diet, smoking, alcohol use, physical inactivity, inflammatory bowel disease, and aging [2].

Breakthroughs in CRC therapy have decreased the mortality of patients with CRC. Current chemotherapeutic options continue to have important side effects due to cytotoxicity and may fail to prevent disease progression [8]. Thus, there is a great interest in new therapeutic approaches for $\mathrm{CRC}$, including phytochemical agents.

Cannabinoids might be substances with possible therapeutic potential for cancer because of their chemotherapeutic effect and their ability to attenuate anorexia, pain, and emesis; these are common side effects of chemotherapy $[9,10]$. This has been proved in several experimental models of CRC, brain cancer, breast cancer, lung cancer, prostate cancer, leukemia, and melanoma [11]. However, to the best of our knowledge, cannabinoids have not been tested in humans as medicines for CRC.

Animal models and cell lines of CRC have tested cannabinoids. This study aims to conduct a systematic review of the research about the effect of cannabinoids on in vivo azoxymethane (AOM) or xenograft CRC models. The outcomes used to assess the effects of cannabinoids, compared with no cannabinoid therapy, were a decrease in the number of preneoplastic lesions (aberrant crypt foci), number, and volume of neoplastic lesions.

\section{Materials and Methods}

The protocol for this study was registered in PROSPERO (International Prospective Register for Systematic Reviews) under CRD42019148356 [12]. This systematic review was performed following the Preferred Reporting Items for Systematic Reviews and Meta-Analyses (PRISMA) statement (Supplementary file) [13].

2.1. Eligibility Criteria. Population. The population should be animal species (no restrictions), used for in vivo models of CRC, either chemically induced (Azoxymethane or DSS) or by xenograft injection. Dose and time of exposure to azoxymethane were not exclusion criteria for this review. We excluded all studies that included only in vitro assessment and studies that evaluated species for noncolorectal cancer models.

Intervention. Studies had to evaluate the beneficial effects of the following cannabinoids: CBD, CBG, O-1602, LYR-8, WIN 55, 212-2, AEA, HU-210, rimonabant, anandamide reuptake inhibitors (VDM11), FAAH inhibitors, and MAGL inhibitors.

Comparators. Studies had to include at least one comparator group of the same animal species used for the intervention group, with similar characteristics (weight, age, sex, exposure to the same environment, and feeding), without exposition to cannabinoid therapy.
Studies. Studies should be experimental in vivo studies of $\mathrm{CRC}$ in mice, with at least one control group. We excluded conference abstracts, narrative reviews, and systematic reviews.

Primary Outcome. There should be a reduction in tumor volume $\left(\mathrm{mm}^{3}\right)$, number of aberrant crypt foci (ACF), and number of tumors comparing intervention and control group.

Secondary Outcome. There should be an expression of apoptosis markers (Bax, caspase-3, caspase-9, annexin V, $\mathrm{PI}$ ), expression of proinflammatory markers (STAT3, NF $\kappa \beta$, TNF- $\alpha$ ), and levels of endocannabinoids.

2.2. Search Strategy. We performed a methodologic and systematic strategic search in the following electronic bibliographic databases: PubMed, Scopus, and Embase (from their inception to December 18, 2019). The last search was run on December 18, 2019. Only full available articles written in English were suitable for assessment. We used the following Medical Subject Headings (MESH) terms in PubMed: "colorectal neoplasms", "colonic neoplasms", "colorectal cancer", "polyps", "rimonabant", “cannabidiol”, "cannabinoids", "azoxymethane", "xenograft", and "mice”.

2.3. Study Selection and Data Collection. The authors EOG and LLT conducted the search independently. Duplicate articles were moved to a different folder and registered in the flowchart. Before the selection process, a test was conducted to evaluate the agreement between evaluators. All titles and summaries of the articles were assessed by EOG and LLT independently based on a selection criterion. The full text of previously selected studies was then reviewed and analyzed. Any disagreement was discussed, and if not resolved, a third author (AVV) was consulted. All selected articles were summarized in a flowchart according to the PRISMA protocol. We used a standardized form with a pilot test to collect the following data: title, author, publication year, type of animal model, sample size, type of cannabinoid, the dose of cannabinoid, the dose of AOM, type of outcome measure, length of the experiment, reduction in ACF formation, reduction in the number of tumors, tumor volume reduction, pathway or function modified by cannabinoids, an increase of endocannabinoid levels, expression of apoptosis markers, and expression of proinflammatory markers.

2.4. Quality Assessment. The risk of bias was independently evaluated by two authors (EOG and LLT) following the Systematic Review Centre for Laboratory animal Experimentation (SYRCLE) risk of bias tool [14]. The domains considered were random sequence generation, baseline characteristics, allocation concealment, random housing, blinding, random outcome assessment, outcome assessor blinding, incomplete outcome data, selective outcome report, and other sources of bias (contamination, the influence of funders, and analysis of errors) [14]. We reviewed each article, and we sought if any of these biases were present. Any discrepancy was discussed between 2 authors (EOG and LLT), and if not resolved, a third investigator intervened (AVV). 
2.5. Data Analysis. Proportions were used as descriptive statistics for primary outcomes. Secondary outcomes were described qualitatively. A meta-analysis or measures of consistency were not performed due to characteristics of the studies and heterogeneity of articles.

\section{Cannabinoids: Pharmacology and Generalities}

Endocannabinoids are lipid mediators, including amides, esters, and ethers of polyunsaturated fatty acids, which were isolated from the porcine brain [15-17]. Anandamide's structure resembles $\triangle 9$-THC structure, and it is synthesized from membrane phospholipids by the enzymes $\mathrm{N}$-acyl phosphatidylethanolamine phospholipase $D$ (NAPE-D) and lysophospholipase $D$ (lyso-PLD) [18]. 2-Arachidonoylglycerol (2-AG) is an arachidonoyl ester, produced from diacylglycerols [18]. Endocannabinoids diffuse into the extracellular space and bind to $\mathrm{CB} 1$ and $\mathrm{CB} 2$ receptors, TRPV1, TRPM8, and GPR55 [18]. Anandamide and 2-AG are reuptake via an extraneuronal monoamine membrane transporter (EMT); then, they are degraded by the fatty acid amide hydrolase (FAAH) and the monoacylglycerol lipase (MAGL), respectively [16, 19]. Most known plant-derived cannabinoids include tetrahydrocannabinol (THC) and cannabidiol (CBD) [20]. These are tricyclic terpenoid compounds bearing a benzopyran moiety soluble in lipids and nonpolar organic solvents [20, 21].

$\Delta 9$-Tetrahydrocannabinol (THC) and anandamide have the highest affinity for the CB1 receptor, while CBD exhibits low affinity for these receptors $[20,21]$. However, CBD has been proved to enhance endocannabinoid levels and indirectly activate $\mathrm{CB}$ receptors [8].

$\mathrm{CB} 1$ receptors constitute one of the most abundant receptors in the central nervous system. In the case of CB2 receptors, these are expressed in cells of the immune and hematopoietic system, spleen, and tonsils, modulating cytokine release and cellular immune migration [16]. Both receptors are metabotropic and belong to the $G$ protein-coupled receptor (GPCR) family, and their activation produces inhibition of the adenylyl cyclase via $G$ proteins (Gi/o) [16]. This decreases cAMP in the cell and activity of protein kinase A [16].

Cannabinoids may have alternative molecular targets other than classical CB1 and CB2 receptors [22]. Recently, orphan GPCRs like the GPR 55, GPR18, and GPR110 have been identified as new targets [22]. There is also increasing evidence that they can interact with ionotropic receptors such as the transient receptor potential cation channel subfamily $\mathrm{V}$ member 1 (TRPV1), and the transient receptor potential cation channel subfamily $M$ member 8 (TRPM8) [23].

The transient receptor potential vanilloid receptor 1 (TRPV1) and the transient receptor potential cation channel subfamily $M$ member 8 (TRPM8) are ionotropic channels that allow $\mathrm{Na}^{+}$and $\mathrm{Ca}^{++}$entry to the cell [24]. Cannabidiol (CBD) and cannabigerol (CBG) close the TRPM8 channel, whereas CBD opens TRPV1 [24].

GPR55 is another GPCR, which is coupled to a G $\alpha 12 / 13$ protein [25]. Several cancer lines like OVACAR3 (ovarian cancer cell line), PC-3, and DU145 (prostate cancer cell lines) exhibit expression of this orphan receptor [25]. Furthermore, Piñeiro et al. showed an autocrine activation of this receptor through his main endogenous agonist lysophosphatidylinositol (LPI) [25]. The receptor acts via activation of $\mathrm{G} \alpha 12$ and Gq family proteins, which activate Ras homolog gene family, member A (RhoA) kinase [26]. Overexpression of GPR55 produces increased levels of pERK in HEK-293, breast carcinoma, and glioma cells, while pAKT levels are increased in ovarian and prostate cancer cells $[25,27]$.

The high expression of GPR55 is also linked to high proliferation indices in human breast tumors and Glioblastoma [26]. The best-studied cannabinoid with actions on the GPR55 in colonic tissue is O-1602 [28]. It is highly speculative that the compound exerts its antineoplastic effects on CRC tissue through the GPR55 receptor, as the cannabinoid has shown agonist activity on this receptor [28]. More research is needed before we can conclude the actions of cannabinoids on this receptor.

Ceramide's synthesis begins with the enzyme serine palmitoyltransferase (SPT) [29]. Gustaffson et al. have demonstrated that the cannabinoids Win55,212-2 and $R$ (+)-methanandamide induce ceramide accumulation mainly through CB1 and CB2 activation, which acts on SPT $[30,31]$. Both studies were performed in mantle cell lymphoma cells (L718, L1547, L1676, and Rec-1) [30, 31]. Furthermore, in neural tissues (rat glioma C6 line and H4 neuroglioma), $R(+)$-methanandamide and JWH-133 (CB2 agonist) also induce ceramide accumulation [32, 33]. Ceramide provokes a loss of mitochondrial membrane potential and caspase activation, subsequently [30, 31].

3.1. Reported Effects of Cannabinoids on CRC. Most cultured colonic cancer cells used for in vitro assessment express CB1, CB2, TRPM8, and GPR55 (G protein-coupled receptor) [34-39]. Additionally, adenomatous polyps and colorectal cancer tissue have increased the amounts of the endogenous cannabinoids AEA and 2-AG (3-fold versus 2-fold, respectively) [40]. This has been suggested to be a mechanism of self-protection against further tumor progression [40, 41]. Cannabinoids and phytocannabinoids have, therefore, effects on colonic cancer tissues since CRC tissues produce those (endogenous cannabinoids) and express some of their receptors (Figure 1).

One of the main effects demonstrated in experimental models is apoptosis. This is proposed to be mediated through the upregulation of endoplasmic reticulum stress-related genes (ATF-4, TRB3), accumulation of reactive oxygen species (ROS), cell cycle arrest in a p-53 independent manner, and activation of proapoptotic proteins (BAX, caspase 3/9) $[38,39,42-44]$. Ceramide enhanced production is another mechanism of apoptosis induction by cannabinoids through the mitochondrial pathway [45]. In these cases, proapoptotic proteins, usually sequestered in the intermembrane space, are released into the cytosol, assembling the "apoptosome" (formed by the binding of cytochrome c, Apaf-1, and procaspase-9) [46]. Procaspase 3 is cleaved by the apoptosome and causes morphological and biochemical changes seen in apoptosis [46]. 


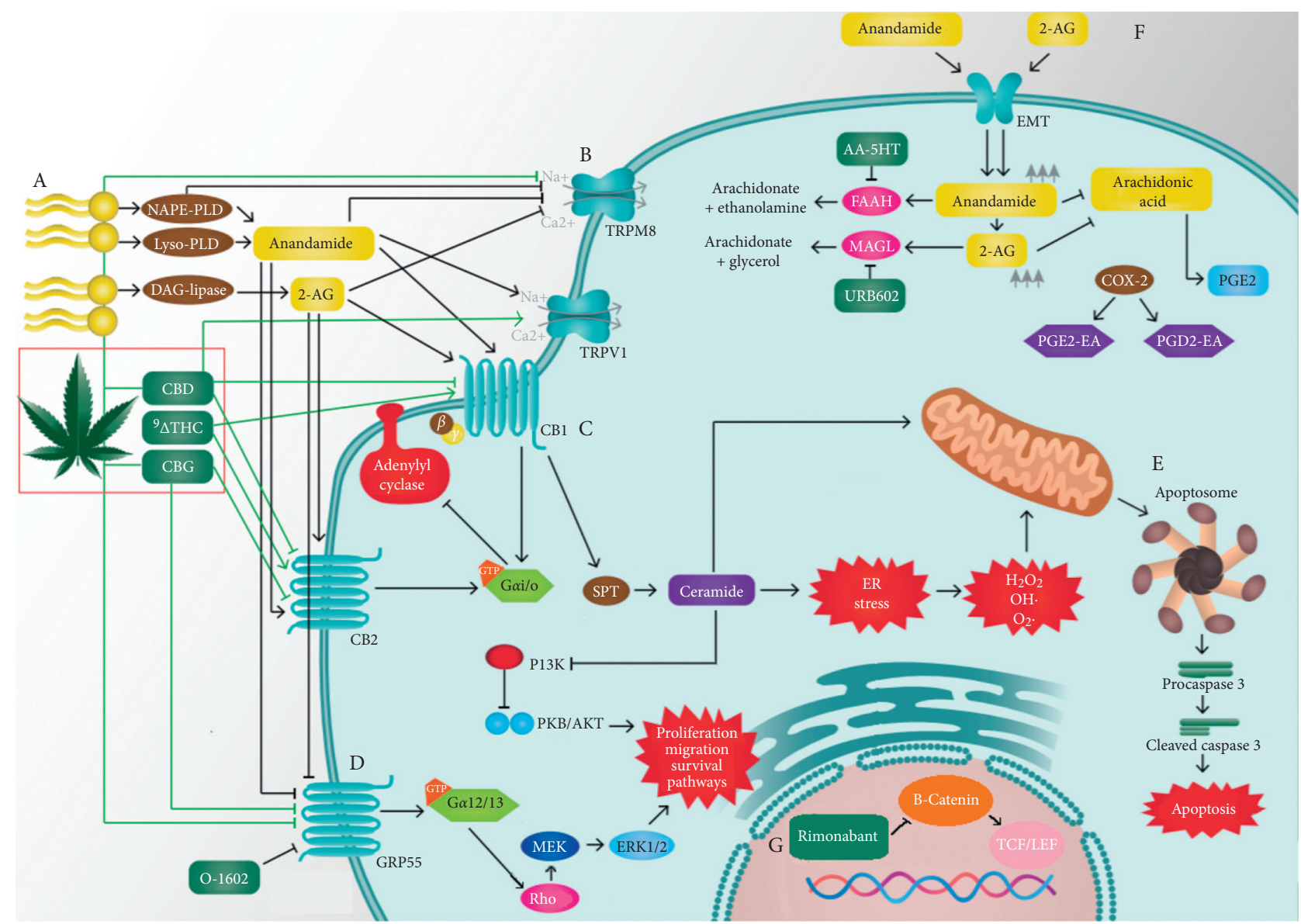

FIGURE 1: Overview of cannabinoids' pharmacology. (A) Synthesis of endocannabinoids from membrane lipids. (B) TRPM8 and TRPV1, ionotropic receptors of cannabinoids. (C) Cannabinoid (CB) receptors 1 and 2 coupled to g protein and adenylyl cyclase, cannabinoids; their respective ligands are shown in the image. (D) GPR55 receptor coupled to g protein, Rho GTPase, and MAPK pathway; its respective ligands are shown in the image. (E) Ceramide synthesis de novo induced by endocannabinoids. (F) Reuptake of endocannabinoids and subsequent metabolism. (G) Apoptosome assembly during the mitochondrial pathway of apoptosis. Executioner caspase is cleaved, and the cell undergoes apoptosis. $(\mathrm{H})$ Rimonabant increases $\beta$-catenin breakdown and decreases the activity of the T-cell factor/lymphoid enhancerbinding factor (TCF/LEF). Other studied effects of cannabinoids not included in the figure are cytotoxic effects (antiproliferative effects), upregulation of estrogen receptors, reduction of proinflammatory markers, antiangiogenic effects (inhibition of proangiogenic factors), induction of chromosomal abnormalities, and mitotic catastrophe.

Cannabinoids also regulate different proliferation, growth, and survival pathways [45]. Different carcinoma cell lines treated with $\triangle 9$-THC also exhibited inhibition of the RAS-MAPK pathway and the phosphatidylinositol 3-kinase pathway (PI3k-AKT) pathway through CB1-receptor activation or ceramide accumulation $[34,45]$.

In vitro studies have also reported that COX-2 metabolites of anandamide (PGE2-EA and PGD2-EA) have growth inhibitory effects in CRC [47-49]. In the case of rimonabant, this is an inverse agonist of CB1 receptors; however, it was demonstrated that this compound counteracts the Wnt/ $\beta$-catenin pathway by decreasing the activity of transcription factors T-cell factor/lymphoid enhancer-binding factor (TCF/ LEF) [50,51]. Other effects of cannabinoids are reported less frequently, including cytotoxic effects similar to 5-Fluorouracil and upregulation of estrogen receptors [52-54].

Contrarily to these findings, in some studies, $\mathrm{CB}$ receptors have been involved in CRC origin. CB1 and CB2 receptors were prognostic markers of survival in advanced
CRC stages (IV) [36]. Moreover, Martínez et al. demonstrated a biphasic effect of synthetic cannabinoids on colon cancer-derived cell line HT29 [55]. Sub-micromolar concentrations $(1 \mu \mathrm{m})$ of $\mathrm{CB}_{2}$-specific agonists stimulate the PI3K/AKT pathway and the transcription factor SNAIL, promoting cell proliferation in this in vitro model [55]. Figure 1 summarizes some of the main mechanisms of cannabinoids on CRC, described in the literature.

\section{Results}

We identified 94 records in electronic databases: 57 in Scopus, 27 in PubMed, and 10 in Embase. Duplicate records were removed, and 76 studies remained. After the title and abstract review, 18 studies were selected, of which only 8 were included in the analysis after the full-text evaluation (Figure 2).

Six studies were excluded because they only included in vitro assessments, three were abstracts from a conference, 


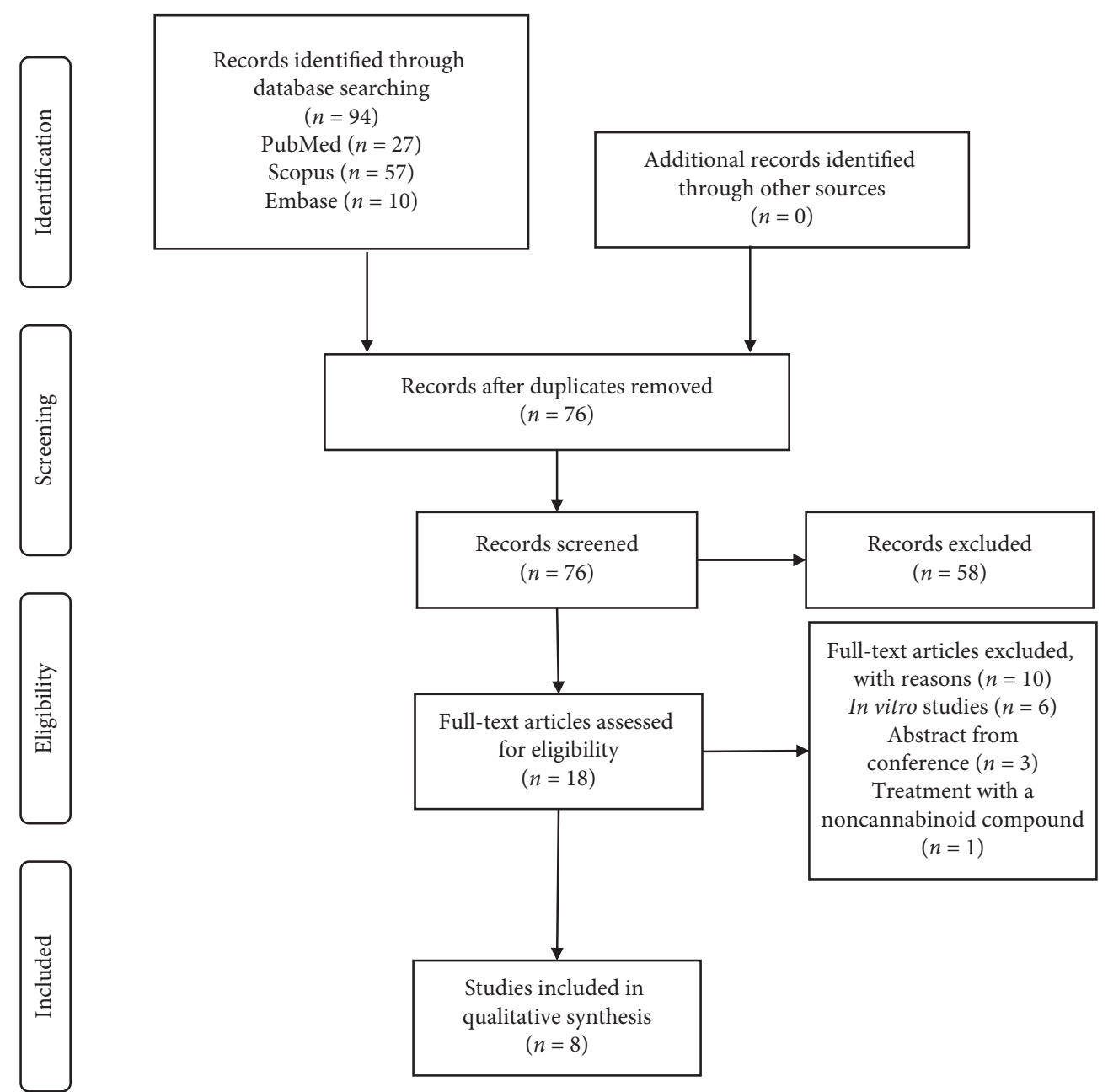

Figure 2: Preferred Reporting Items for Systematic Reviews and Meta-Analysis flowchart detailing the search strategy and study selection output.

and their full-text article could not be found, and one study assessed a noncannabinoid compound.

4.1. Characteristics of Included Studies. The characteristics of the included studies are summarized in Table 1 . Seven studies were AOM-colorectal cancer models [7, 8, 28, 35, 38, 56, 57]. The protocol for 4 of the studies with this model was four single doses of $10 \mathrm{mg} / \mathrm{kg}$ ( $40 \mathrm{mg} / \mathrm{kg}$ in total, intraperitoneally) at the beginning of the first, second, third, and fourth week $[7,8,38,56]$. Two studies performed a model, in which $3 \mathrm{mg} /$ $\mathrm{kg}$ was given intraperitoneally at days 1 and 5 during the first week, $3 \mathrm{mg} / \mathrm{kg}$ at days 1 and 5 during the third week, and $2 \mathrm{mg} / \mathrm{kg}$ at days 1 and 5 during the $17^{\text {th }}$ week $[35,57]$. In Kargl et al.'s research, animals received a single intraperitoneal injection of AOM $(10 \mathrm{mg} / \mathrm{kg})$ [28].

One of these studies was a combined model of AOM/ DSS (Dextran sodium sulfate) [28]. Four studies were xenograft models of colorectal cancer, which implanted a single cell suspension of either HCT116 (3 studies) $[8,38,56]$ or HT29 (1 study) [58] colorectal cancer cells within a heterotopic flank of the host (4 studies) $[8,38,56,58]$. The most common host used for studies was IRC mice (4 studies)
$[7,8,38,56]$, followed by C57BL/6N (2 studies) [35, 57], CD1 mice (1 study) [28], and BALB/c mice (1 study) [58]. Cannabinoids and doses assessed were highly variable across the studies (Table 1).

However, CBD was the most common, being evaluated in two of the studies $[7,8]$. Romano et al. tested different cannabis extracts, with a high content of CBD [8].

4.2. Risk of Bias. Measures to reduce performance bias were not reported in any of the publications, making them highly likely to have performance bias [7, 8, 28, 35, 38, 56-58]. There was a high risk of detection bias in all studies because there was no random outcome assessment [7, 8, 28, 35, 38, 56-58]. We found that other potential sources of bias were present in half of the studies as pharmaceutical companies funded them $[7,8,38,57]$. Some of the domains had to be scored as unclear risk of bias, as there were few details about the methods used by each author $[7,8,28,35,38,56-58]$ (Table 2).

4.3. Reported Outcomes. The reduction of ACF formation could be extracted in four of the studies included $[7,8,35,57]$. CBD BS and Rimonabant achieved the highest 
TABLE 1: Summary of study characteristics.

\begin{tabular}{|c|c|c|c|c|c|c|}
\hline $\begin{array}{l}\text { Author, } \\
\text { year }\end{array}$ & Animal model & $\begin{array}{l}\text { Sample size } \\
\text { and number of } \\
\text { groups in the } \\
\text { AOM model }\end{array}$ & $\begin{array}{c}\text { Sample size and number } \\
\text { of groups in the } \\
\text { xenograft model }\end{array}$ & $\begin{array}{c}\text { Cannabinoid and } \\
\text { dose }^{\text {s }}\end{array}$ & Main outcome measures & $\begin{array}{l}\text { Length of } \\
\text { the } \\
\text { experiment }\end{array}$ \\
\hline $\begin{array}{l}\text { Aviello, } \\
\text { et al. } 2012 \\
\text { [7] }\end{array}$ & $\begin{array}{l}\text { ICR male mice } \\
\text { AOM-induced } \\
\text { CRC }\end{array}$ & $\begin{array}{l}N=10 \text { per } \\
\text { group. } \\
\text { Group 1= } \\
\text { Vehicle } \\
\text { Group 2= } \\
\text { AOM plus } \\
\text { vehicle } \\
\text { Group } 3= \\
\text { AOM plus } \\
\text { CBD } \\
\text { Group 4= } \\
\text { AOM plus } \\
\text { CBD }\end{array}$ & N/A & $\begin{array}{c}\text { Experimental } \\
\text { group 3: CBD } \\
1 \mathrm{mg} / \mathrm{kg} \text { IP } \\
\text { Experimental } \\
\text { group 4: CBD } 5 \\
\text { mg/kg IP } \\
\text { Three times per } \\
\text { week }\end{array}$ & $\begin{array}{l}\text { 1. Decrease in ACF } \\
\text { formation } \\
\text { 2. Increase in expression } \\
\text { of cyclooxygenase-2 } \\
\text { (COX-2), inducible nitric } \\
\text { oxide synthase (iNOS), } \\
\text { and caspase-3 } \\
\text { 3. Increase in } \\
\text { phosphorylation of AKT } \\
\text { 4. MTT assay for the } \\
\text { antiproliferative effect } \\
\text { 5. Increase in } \\
\text { endocannabinoids levels }\end{array}$ & $\begin{array}{l}\text { Three } \\
\text { months }\end{array}$ \\
\hline $\begin{array}{l}\text { Borrelli, } \\
\text { et al. } 2014 \\
\text { [38] }\end{array}$ & $\begin{array}{c}\text { ICR male and } \\
\text { female mice } \\
\text { AOM-induced } \\
\text { CRC/Xenograft } \\
\text { model of HCT } 116 \\
\text { colon carcinoma } \\
\text { cells }\end{array}$ & $\begin{array}{l}N=10 \text { per } \\
\text { group. } \\
\text { Group } 1= \\
\text { Vehicle } \\
\text { Group 2= } \\
\text { AOM plus } \\
\text { vehicle } \\
\text { Group } 3= \\
\text { AOM plus } \\
\text { CBG } \\
\text { Group 4= } \\
\text { AOM plus } \\
\text { CBG }\end{array}$ & $\begin{array}{l}\text { HCT } 116 \text { cells }\left(2.5 \times 10^{6}\right) \\
\text { were injected } \\
\text { subcutaneously into the } \\
\text { right flank of each } \\
\text { athymic mice. At } 10 \text { days } \\
\text { after inoculation (once } \\
\text { tumors had reached a } \\
\left.\text { size of } 550-650 \mathrm{~mm}^{3}\right) \text {, } \\
\text { mice were randomly } \\
\text { assigned to one control } \\
\text { group and three treated } \\
\text { groups }\end{array}$ & $\begin{array}{c}\text { AOM model: } \\
\text { Experimental } \\
\text { group 3: CBG } 1 \\
\text { mg/kg IP } \\
\text { Experimental } \\
\text { group 4: CBG } 5 \\
\text { mg/kg IP three } \\
\text { times per week } \\
\text { Xenograft model: } \\
\text { Experimental } \\
\text { group 1: CBG } 1 \\
\text { mg/kg IP } \\
\text { Experimental } \\
\text { group 3: CBG } 3 \\
\text { mg/kg IP } \\
\text { Experimental } \\
\text { group 4: CBG } 10 \\
\text { mg/kg IP t } \\
\text { hree times per week }\end{array}$ & $\begin{array}{l}\text { 1. Decrease in tumor } \\
\text { growth } \\
\text { 2. Decrease in ACF } \\
\text { formation } \\
\text { 3. Decrease in CB } \\
\text { receptors expression } \\
\text { 4. MTT assay for } \\
\text { antiproliferative effect } \\
\text { 5. CBG antagonism at } \\
\text { TRPM8 receptor } \\
\text { 6. Increase in ROS } \\
\text { production } \\
\text { 7. Increase in CHOP } \\
\text { mRNA expression } \\
\text { 8. Increase in caspase } 3 / 7 \\
\text { enzymatic assay }\end{array}$ & $\begin{array}{l}\text { Three } \\
\text { months }\end{array}$ \\
\hline $\begin{array}{l}\text { Izzo, et al. } \\
2008 \text { [35] }\end{array}$ & $\begin{array}{l}\text { C57BL/6N female } \\
\text { mice AOM- } \\
\text { induced CRC }\end{array}$ & $\begin{array}{l}N=6 \text { per } \\
\text { group. } \\
\text { Group } 1= \\
\text { vehicles } \\
\text { Group 2= } \\
\text { AOM plus the } \\
\text { vehicle } \\
\text { Group 3= } \\
\text { AOM plus } \\
\text { AA-5HT } \\
\text { Group 4= } \\
\text { AOM plus } \\
\text { VDM11 } \\
\text { Group 5= } \\
\text { AOM plus } \\
\text { HU210 }\end{array}$ & N/A & $\begin{array}{c}\text { AA-5HT* } 5 \mathrm{mg} / \mathrm{kg} \\
\text { IP } \\
\mathrm{N}-(2-\mathrm{methyl}-3- \\
\text { hydroxy-phenyl)- } \\
5,8,11,14 \text {-eicosa- } \\
\text { tetraenamide]) }{ }^{* *} \text { : } \\
5 \\
\mathrm{mg} / \mathrm{kg} \mathrm{IP} \\
\mathrm{HU} 210: \\
0.1 \\
\mathrm{mg} / \mathrm{kg} \text { IP } \\
\text { Given daily during } \\
\text { the experiment }\end{array}$ & $\begin{array}{l}\text { 1. Decrease in ACF } \\
\text { formation } \\
\text { 2. Increase in } \\
\text { endocannabinoids levels } \\
\text { 3. Increased expression of } \\
\text { caspase-3 and caspase- } 9\end{array}$ & Six months \\
\hline $\begin{array}{l}\text { Kargl, } \\
\text { et al. } 2013 \\
{[28]}\end{array}$ & $\begin{array}{l}\text { CD1 male mice } \\
\text { AOM/DSS- } \\
\text { induced CRC }\end{array}$ & $\begin{array}{l}N=12 \text { per } \\
\text { group } \\
\text { Group } 2= \\
\text { AOM/DSS } \\
\text { plus the } \\
\text { vehicle } \\
\text { Group } 1= \\
\text { AOM/DSS } \\
\text { plus O-1602 }\end{array}$ & N/A & $\begin{array}{l}\text { O-1602 } 3 \mathrm{mg} / \mathrm{kg} \text { IP } \\
\text { every second day } \\
\text { over four weeks }\end{array}$ & $\begin{array}{l}\text { 1. Decrease in tumor } \\
\text { growth } \\
\text { 2. Decrease in } \\
\text { phosphorylation of NF } \kappa \beta \\
\text { and STAT3 } \\
\text { 3. Increase in expression } \\
\text { of BAX and P534 } \\
\text {. Increase in a } \\
\text { nnexin V/PI expression } \\
\text { 5. Decreased expression of } \\
\text { TNF- } \alpha\end{array}$ & $\begin{array}{l}\text { Twelve } \\
\text { weeks }\end{array}$ \\
\hline
\end{tabular}


TABLE 1: Continued.

\begin{tabular}{|c|c|c|c|c|c|c|}
\hline $\begin{array}{l}\text { Author, } \\
\text { year }\end{array}$ & Animal model & $\begin{array}{l}\text { Sample size } \\
\text { and number of } \\
\text { groups in the } \\
\text { AOM model }\end{array}$ & $\begin{array}{l}\text { Sample size and number } \\
\text { of groups in the } \\
\text { xenograft model }\end{array}$ & $\begin{array}{c}\text { Cannabinoid and } \\
\text { dose }^{9}\end{array}$ & Main outcome measures & $\begin{array}{l}\text { Length of } \\
\text { the } \\
\text { experiment }\end{array}$ \\
\hline $\begin{array}{l}\text { Pagano, } \\
\text { et al. } 2017 \\
{[56]}\end{array}$ & $\begin{array}{l}\text { ICR male or } \\
\text { female mice } \\
\text { AOM-induced } \\
\text { CRC/Xenograft } \\
\text { model of HCT } 116 \\
\text { colon carcinoma } \\
\text { cells }(N=10)\end{array}$ & $\begin{array}{l}N=10 \text { per } \\
\text { group. } \\
\text { Group 1= } \\
\text { Vehicles } \\
\text { Group 2= } \\
\text { AOM plus } \\
\text { vehicle } \\
\text { Group 3= } \\
\text { AOM plus } \\
\text { URB-602 }\end{array}$ & $\begin{array}{l}\text { HCT } 116 \text { cells }\left(2.5 \times 10^{6}\right) \\
\text { were injected } \\
\text { subcutaneously into the } \\
\text { right flank of each } \\
\text { athymic mice and at } \\
10 \text { days after inoculation } \\
\text { (once tumors had } \\
\text { reached a size of } \\
250-300 \mathrm{~mm}^{3} \text { ), mice } \\
\text { were randomly assigned } \\
\text { to one control and } \\
\text { treated group. } \\
N=5 \text { animals per group }\end{array}$ & $\begin{array}{c}\text { AOM and } \\
\text { xenograft model: } \\
\text { URB- } 602 \\
+5 \\
\text { mg/kg IP three } \\
\text { times a week }\end{array}$ & $\begin{array}{l}\text { 1. Increase in expression } \\
\text { of monoacylglycerol lipase } \\
\text { (MAGL) in CRC cells and } \\
\text { xenograft tissue } \\
\text { 2. Decrease in tumor } \\
\text { growth } \\
\text { 3. Increase in } \\
\text { endocannabinoid levels } \\
\text { 4. Decreased expression of } \\
\text { VEGF and FGF-2 } \\
\text { 5. Decrease in cyclin-D1 } \\
\text { and p27KIP expression }\end{array}$ & $\begin{array}{l}\text { Three } \\
\text { months }\end{array}$ \\
\hline $\begin{array}{l}\text { Romano, } \\
\text { et al. } 2014 \\
\text { [8] }\end{array}$ & $\begin{array}{l}\text { ICR male mice } \\
\text { AOM-induced } \\
\text { CRC/Xenograft } \\
\text { model of HCT } 116 \\
\text { colon carcinoma } \\
\text { cells }\end{array}$ & $\begin{array}{l}\text { †† } \\
\text { Group 1= } \\
\text { Vehicle } \\
\text { Group 2= } \\
\text { AOM plus } \\
\text { vehicle } \\
\text { Group 3= } \\
\text { AOM plus } \\
\text { CBD BDS }\end{array}$ & $\begin{array}{l}\text { HCT } 116 \text { cells }\left(2.5 \times 10^{6}\right) \\
\text { were injected } \\
\text { subcutaneously into the } \\
\text { right flank of each } \\
\text { athymic mice and at } \\
10 \text { days after inoculation } \\
\text { (once tumors had } \\
\text { reached a size of } \\
\left.300 \mathrm{~mm}^{3}\right) \text {, mice were } \\
\text { randomly assigned to } \\
\text { control and treated } \\
\text { group with CBD BDS }\end{array}$ & $\begin{array}{c}\text { AOM and } \\
\text { xenograft model: } \\
\text { CBD BDS } 5 \\
\text { mg/kg IP three } \\
\text { times a week }\end{array}$ & $\begin{array}{l}\text { 1. Decrease in tumor } \\
\text { growth } \\
\text { 2. Decrease in ACF } \\
\text { formation } \\
\text { 3. MTT assay for the } \\
\text { antiproliferative effect }\end{array}$ & $\begin{array}{l}\text { Three } \\
\text { months }\end{array}$ \\
\hline $\begin{array}{l}\text { Santoro, } \\
\text { et al. } 2009 \\
{[57]}\end{array}$ & $\begin{array}{l}\text { C57BL/6N female } \\
\text { mice AOM- } \\
\text { induced CRC }\end{array}$ & $\begin{array}{l}N=9 \text { per } \\
\text { group. } \\
\text { Group } 1= \\
\text { Vehicle } \\
\text { Group 2= } \\
\text { AOM plus } \\
\text { vehicle } \\
\text { Group } 3= \\
\text { AOM plus } \\
\text { rimonabant }\end{array}$ & N/A & $\begin{array}{l}\text { Rimonabant } 3 \mathrm{mg} / \\
\text { kg IP given daily } \\
\text { during the } \\
\text { experiment }\end{array}$ & $\begin{array}{l}\text { 1. Decrease in ACF } \\
\text { formation } \\
\text { 2. Increase in expression } \\
\text { of cyclin B1 } \\
\text { /cdk1 complex } \\
\text { 3. Decreased } \\
\text { phosphorylation of p38/ } \\
\text { MAPK and PARP-1 } \\
\text { 4. Increase in mitotic } \\
\text { index, polyploidy, and } \\
\text { chromosome aberrations } \\
\text { 5. Decreased } \\
\text { phosphorylation of Chk1 }\end{array}$ & Six months \\
\hline $\begin{array}{l}\text { Thapa, } \\
\text { et al. } 2012 \\
{[58]}\end{array}$ & $\begin{array}{c}\text { BALB/c nude } \\
\text { mice xenograft } \\
\text { model of HT-29 } \\
\text { of colon } \\
\text { carcinoma cells }\end{array}$ & N/A & $\begin{array}{l}\text { HT } 29 \text { cells }\left(5 \times 10^{6}\right) \\
\text { were injected } \\
\text { subcutaneously into the } \\
\text { rear flanks of each } \\
\text { BALB } / c \text { nude mice and } \\
\text { once tumors had } \\
\text { reached a size of } \\
50 \mathrm{~mm}^{3} \text {, mice were } \\
\text { randomly assigned to } \\
\text { control and treated } \\
\text { groups. } n=6 \text { animal per } \\
\text { group }\end{array}$ & $\begin{array}{l}\text { LYR-8 } 10 \mathrm{mg} / \mathrm{kg} \text { IP } \\
\text { given daily during } \\
\text { the experiment }\end{array}$ & $\begin{array}{l}\text { 1. Decrease in tumor } \\
\text { growth } \\
\text { 2. Decreased expression of } \\
\text { COX-2, vascular } \\
\text { endothelial growth factor } \\
\text { (VEGF), and hypoxia- } \\
\text { inducible factor (HIF-1 } \alpha \text { ) }\end{array}$ & Unknown \\
\hline
\end{tabular}

${ }^{*}$ FAAH inhibitor. ${ }^{* *}$ VDM11 inhibitor. ${ }^{\dagger}$ MAGL inhibitor. ${ }^{9}$ All doses were started one week before the first injection of AOM. ${ }^{\dagger \dagger}$ Sample size is not described in the article. CBD: cannabidiol, CBG: cannabigerol, IP: intraperitoneal, AOM: azoxymethane, AA-5HT: N-arachidonoyl-serotonin, BDS: botanical drug substance, ACF: aberrant crypt foci, ROS: reactive oxygen species, N/A: not applicable. 
TABLE 2: Quality assessment.

\begin{tabular}{|c|c|c|c|c|c|c|c|c|c|c|}
\hline \multirow[b]{2}{*}{ Author } & \multirow[b]{2}{*}{$\begin{array}{l}\text { Random } \\
\text { sequence } \\
\text { generation }\end{array}$} & \multicolumn{2}{|l|}{ Selection bias } & \multicolumn{2}{|c|}{ Performance bias } & \multicolumn{2}{|c|}{ Detection bias } & \multirow{2}{*}{$\begin{array}{c}\text { Attrition } \\
\text { bias } \\
\text { Incomplete } \\
\text { outcome } \\
\text { data }\end{array}$} & \multirow{2}{*}{$\begin{array}{c}\text { Reporting } \\
\text { bias } \\
\text { Selective } \\
\text { outcome } \\
\text { report }\end{array}$} & \multirow{2}{*}{$\begin{array}{c}\text { Other } \\
\text { biases } \\
\text { Other } \\
\text { sources } \\
\text { of bias }\end{array}$} \\
\hline & & $\begin{array}{c}\text { Baseline } \\
\text { characteristics }\end{array}$ & $\begin{array}{l}\text { Allocation } \\
\text { concealment }\end{array}$ & $\begin{array}{l}\text { Random } \\
\text { housing }\end{array}$ & Blinding & $\begin{array}{c}\text { Random } \\
\text { outcome } \\
\text { assessment }\end{array}$ & $\begin{array}{c}\text { Outcome } \\
\text { assessor } \\
\text { blinding }\end{array}$ & & & \\
\hline $\begin{array}{l}\text { Aviello, } \\
\text { et al. } 2012 \\
\text { [7] }\end{array}$ & Unclear & Yes & Unclear & Yes & Unclear & No & Unclear & Yes & Yes & Yes \\
\hline $\begin{array}{l}\text { Borrelli, } \\
\text { et al. } 2014 \\
{[38]}\end{array}$ & Unclear & Yes & Unclear & Yes & Unclear & No & Unclear & Yes & Yes & Yes \\
\hline $\begin{array}{l}\text { Izzo, et al. } \\
2008 \text { [35] }\end{array}$ & Unclear & Yes & Unclear & Yes & Unclear & No & Unclear & Yes & Yes & No \\
\hline $\begin{array}{l}\text { Kargl, } \\
\text { et al. } 2013 \\
{[[28]}\end{array}$ & Unclear & Yes & Unclear & Yes & Unclear & No & Unclear & Yes & Yes & Yes \\
\hline $\begin{array}{l}\text { Pagano, } \\
\text { et al. } 2017 \\
[56]]\end{array}$ & Unclear & Yes & Unclear & Yes & Unclear & No & Unclear & Yes & Yes & No \\
\hline $\begin{array}{l}\text { Romano, } \\
\text { et al. } 2014 \\
{[8]}\end{array}$ & Unclear & Yes & Unclear & Yes & Unclear & No & Unclear & Yes & Yes & No \\
\hline $\begin{array}{l}\text { Santoro, } \\
\text { et al. } 2009 \\
{[57]}\end{array}$ & Unclear & Yes & Unclear & Yes & Unclear & No & Unclear & Yes & Yes & Yes \\
\hline $\begin{array}{l}\text { Thapa, } \\
\text { et al. } 2012 \\
\text { [58] }\end{array}$ & Unclear & Yes & Unclear & Yes & Unclear & No & Unclear & Yes & Yes & No \\
\hline
\end{tabular}

SYRCLE's risk of bias tool for animal studies [14].

reduction ( $86 \%$ and $75.4 \%$, respectively), while sole CBD did not have high reduction percentages $(33 \%)$ [7, 8, 35, 57]. Only the study of Romano et al. reported a reduction in polyps' formation (79\%) with CBD BS [8]. A reduction in the number of tumors was assessed in only three studies, with low reduction percentages $[7,8,28]$. Reduction of volume tumor was more evident in the xenograft models of Kargl et al. and Pagano et al., which used O-1602 and one MAGL inhibitor, respectively $[28,56]$. LYR- 8 and CBD BDS did not show a marked reduction of volume in the xenografts than the other cannabinoids $[8,58]$. Among the mechanisms reported for cannabinoids effects, induction of apoptosis (4 studies) [7, 28, 35, 38], antiproliferative effects (3 studies) $[7,8,38]$, and angiogenesis inhibition (2 studies) $[56,58]$ were the most common (Table 3 ).

In these studies, specific markers of apoptosis, mainly caspase3 , and caspase-9, were augmented in CRC tissues treated with CBD, CBG, AA-5HT, VDM11, HU210, and O-1602 [7, 28, 35]. Caspase enzymes are responsible for the protease cascade of apoptosis, being hallmarks of programmed cell death [46].

Borrelli et al. demonstrated that CBG antagonizes TRPM8 through inhibition of intracellular calcium increase, with a rise in apoptosis markers [38]. Pharmacological enhancement of endocannabinoid levels was observed in three of the included studies [7, 35, 56]. Izzo et al. used in their study AA-5HT, a FAAH inhibitor, and VDM11, an endocannabinoid reuptake inhibitor, while Pagano et al. assessed URB602, a MAGL inhibitor $[35,56]$. On the other hand, Romano et al. demonstrated an antiproliferative effect of CBD in MTT assay, by indirect activation of CB1 and CB2 receptors [8].

Two studies demonstrated that angiogenic factors (VEGF, FGF, and HIF) were downregulated by the direct action of URB602 and the synthetic cannabinoid LYR-8 $[56,58]$. In the case of rimonabant, it provoked a phenomenon called "mitotic catastrophe" as its mechanism of action [50]. Mitotic catastrophe is a phenomenon that has been studied in MCF7 and HeLa cells, in which cell cycle progression is inhibited due to an arrest of cells in the G2/M phase of the cell cycle [59]. This is provoked by high amounts of damaged DNA (including high amounts of cells with polyploidy) and apoptosis induction through activation of p53 [59]. This molecular effect is characteristic of the antineoplastic medicine paclitaxel [59]. Other reported effects of cannabinoids include the reduction of proinflammatory markers [7, 28]. Kargl et al. showed that SW480 and HT-29 cells treated with O-1602 could reduce the expression of TNF- $\alpha$, phosphorylation of NF $\kappa \beta$, and STAT3. TNF- $\alpha$ is a cytokine, which exerts a dual role in immunomodulation (inflammation, immune surveillance, and hematopoiesis) and tumorigenesis [60], while the transcription factor, $N F \kappa \beta$, regulates proinflammatory cytokines (TNF- $\alpha$ and IL-1), and it has a pathogenic function in cancer and inflammation $[61,62]$. In the case of STAT3, this belongs to a family of proteins, activated mainly by IL-6, which are linked to inflammation-associated tumorigenesis [63]. 


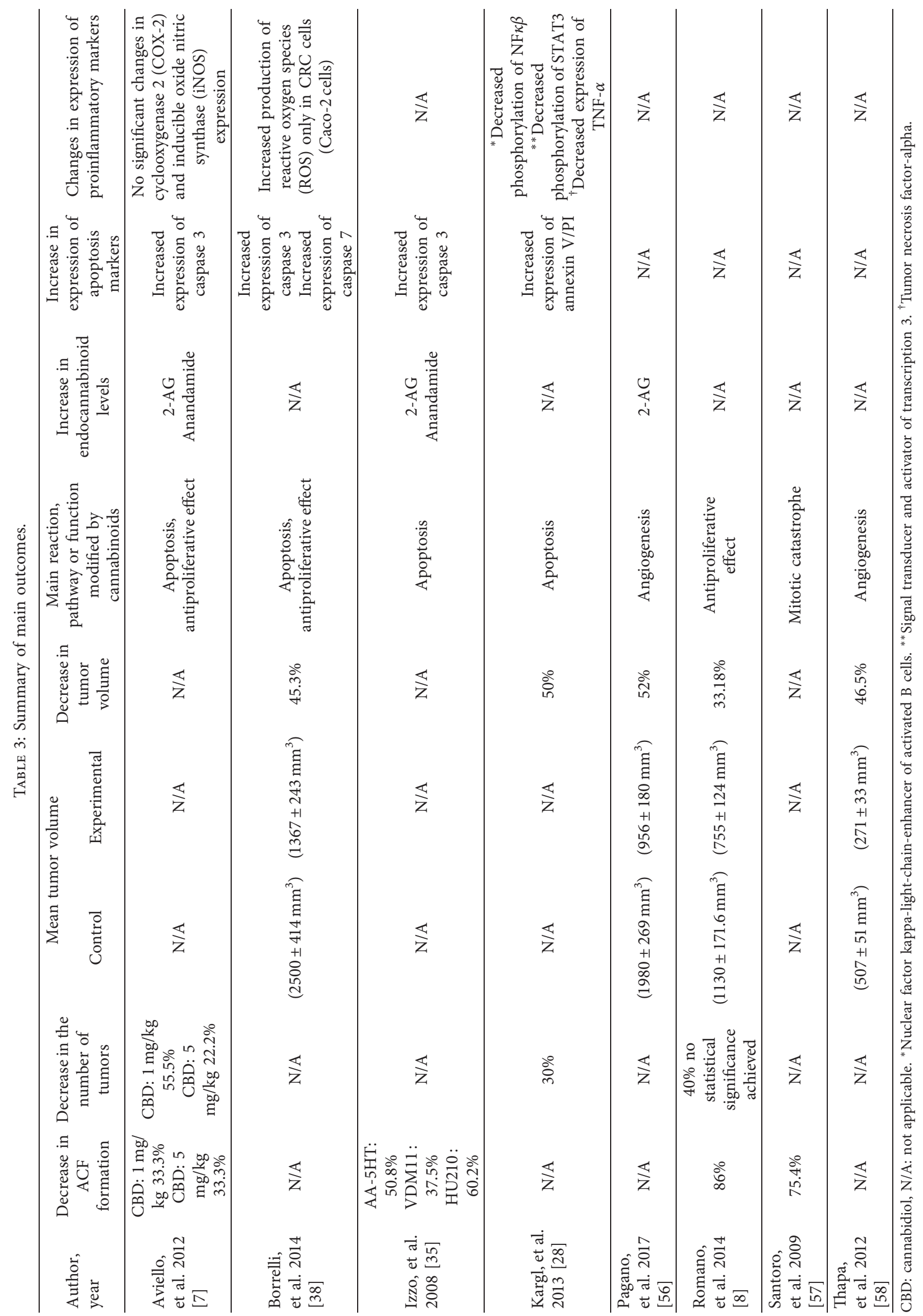




\section{Discussion}

It was observed across the studies that cannabinoids can reduce the development of preneoplastic lesions (ACF) and tumor growth of colorectal cancer in chemically induced CRC and xenograft models. ACF arise from a stem cell in the colonic crypts and represent abnormalities before polyp formation, being regarded as the earliest preneoplastic lesions of CRC [64]. The most common genetic changes involved in ACF formation are mutations of the protein KRAS and microsatellite instability; both are key events in the two main pathways of CRC genesis [64]. Cannabinoids (CBD, AA-5HT, VDM11, HU210, and rimonabant) have chemopreventive potential, as they were able to attenuate colon carcinogenesis in vivo $[7,8,35,57]$.

The MTT (3-[4,5-dimethylthiazol-2-yl]-2,5 diphenyl tetrazolium bromide) assay determines the mitochondrial activity an indirect measure of the number of viable cells [65]. CBD and CBG have cytotoxic effects on CRC tissue and cells, as they were tested either by MTT assay or ${ }^{3} \mathrm{H}$-thymidine incorporation with a significant decrease of cell proliferation $[7,8,38]$. This makes them possible candidates for further research on CRC cytotoxic drugs.

In a prospective human study, researchers achieved a tumor volume reduction rate (measured by MRI-volumetric techniques), of $51.7 \%$ in patients treated with four cycles of FOLFOX [66]. In this systematic review, we found that various cannabinoids could achieve similar reduction rates of the tumor volume (33.18\%-52\%, for in vivo research).

All studies used a diverse variety of cannabinoid compounds and doses, and several physiological mechanisms were elucidated $[7,8,28,35,38,56-58]$. Among them, we highlight apoptosis, angiogenesis inhibition, and mitotic catastrophe $[7,8,28,35,38,56-58]$. Half of the studies exhibited an increase in expression of executioner caspases, demonstrating that CBD, CBG, AA-5HT, VDM11, HU210, and $\mathrm{O}-1602$ have apoptosis as their main mechanism against CRC $[7,28,35,38]$.

Tumor growth and metastasis depend on angiogenesis because, in the absence of vascular support, tumors may become necrotic or even apoptotic [67]. URB-602 and LYR8 have antiangiogenic mechanisms, as proven in their studies, with similar actions to bevacizumab (inhibiting VEGF) [56, 58].

The strengths of this review include being the first study to our knowledge that has systematically reviewed the experimental evidence of cannabinoids in colorectal cancer, as there is no study in humans to date. The review used a comprehensive search strategy in a wide range of registries and data sources and used a well-known quality assessment (SYRCLE's risk bias tool) [14], and the manuscript was registered in the PROSPERO [12]. However, some limitations were found. The main limitation of this study was that animal models, outcomes, and cannabinoids tested were not the same across studies $[7,8,28,35,38,56,57]$. The quality assessment indicated that all the studies had methodological limitations and were at risk of bias $[7,8,28,35,38,56,57]$. The eight studies did not explicitly state blinding and allocation concealment on their methods $[7,8,28,35,38,56,57]$. Thus, it was impossible to determine if certain risks were present. Four studies were founded by pharmaceutical companies, which represent a significant bias $[7,8,38,57]$. We believe that these were not significant drawbacks, as we did not perform a metaanalysis.

Current chemotherapy generates high costs and high toxicity for CRC treatment [68]. CRC therapy includes regimes such as FOLFOX (5-fluorouracil, leucovorin, and oxaliplatin), FOLFIRI (5-fluorouracil, leucovorin, and irinotecan), recombinant monoclonal antibodies like cetuximab, and bevacizumab [68]. It has been reported that FOLFOX and FOLFIRI have a high incidence of neutropenia ( $41.7 \%$ and $24 \%$, respectively); additionally, a high percentage of patients (18\%) under FOLFOX develop neurologic symptoms due to toxicity, and in a high percentage of patients treated with cetuximab, gastrointestinal symptoms like diarrhea are present (13-25\%) [69]. Moreover, chemotherapy during eight weeks in the USA for CRC is estimated to generate high costs for FOLFOX/bevacizumab (\$21033) and FOLFIRI/cetuximab (\$30675) [70].

New molecules as effective as the current chemotherapy need to be synthesized, with less cytotoxic effects. Cannabinoid molecules are not as expensive as monoclonal antibodies and are proven that they have antiproliferative, proapoptotic, and chemopreventive effects on CRC. The next step is to conduct more in vivo research of these compounds, before proceeding to human beings, to determine whether these results are reproducible.

\section{Conclusions}

Overall, there is no robust evidence so far to introduce cannabinoids to the clinical practice as adjuvants of chemotherapy or the main treatment of CRC because no human models have tested these compounds, and only eight in vivo experimental models have been conducted and reported in the literature, during the assessed period. Nevertheless, current literature findings demonstrate that cannabinoids might have potential as antineoplastic agents because they can reduce tumor volume and ACF formation. Induction of apoptosis through several mechanisms is the main action of cannabinoids on CRC, while inhibition of angiogenesis and mitotic catastrophe were also reported. It is crucial to conduct more experimental studies before conducting research on humans, providing high-quality evidence on the efficacy and safety of cannabinoids for treating CRC.

\section{Abbreviations}

TRPV1: Transient receptor potential receptor vanilloid 1 receptor

TRPM8: Transient receptor potential cation channel subfamily $\mathrm{M}$ member 8

CB: $\quad$ Cannabinoid

GPCR: G protein-coupled receptor

ER: $\quad$ Endoplasmic reticulum

CBD: Cannabidiol

CBG: Cannabigerol

THC: Tetrahydrocannabinol 
NAPE-D: N-acyl phosphatidylethanolamine phospholipase D

lyso- $\quad$ Lysophospholipase D

PLD:

2-AG: 2-Arachidonoyl-glycerol

EMT: Extraneuronal monoamine membrane transporter

FAAH: Fatty acid amide hydrolase

MAGL: Monoacylglycerol lipase

COX-2: Cyclooxygenase-2

AA-5HT: N-arachidonoyl-serotonin

ROS: $\quad$ Reactive oxygen species

SPT: $\quad$ Serine palmitoyltransferase

PKB: $\quad$ Protein kinase B

TCF/ T-cell factor/lymphoid enhancer-binding factor

LEF:

CRC: $\quad$ Colorectal cancer

ACF: Aberrant crypt foci

FOLFOX: 5-Fluorouracil, Leucovorin, Oxaliplatin

FOLFIRI: 5-Fluorouracil, Leucovorin, Irinotecan

AOM: Azoxymethane

DSS: Dextran sodium sulfate.

\section{Data Availability}

The datasets used and/or analyzed during the current study are available from the corresponding author upon reasonable request.

\section{Conflicts of Interest}

The authors declare that they have no conflicts of interest.

\section{Authors' Contributions}

E. O. G., A. V. V., and A. V. C. conceptualized the study and developed the research protocol. E. O. G., L. L. T., J. A. G., and D. P. T. identified articles for full-text review and extracted the data that matched the inclusion criteria. E. O. G. and L. L. T. performed the qualitative synthesis of the articles. All authors contributed to the writing of the manuscript. E. O. G. and A. V. V. polished and revised the manuscript.

\section{Supplementary Materials}

Supplementary file 1: the PRISMA statement of this study. Supplementary file 2: the search strategy used for this study. (Supplementary Materials)

\section{References}

[1] R. L. Siegel, K. D. Miller, S. A. Fedewa et al., "Colorectal cancer statistics, 2017," CA: A Cancer Journal for Clinicians, vol. 67, no. 3, pp. 177-193, 2017.

[2] B. Ansa, S. Coughlin, E. Alema-Mensah, and S. Smith, "Evaluation of colorectal cancer incidence trends in the United States (2000-2014)," Journal of Clinical Medicine, vol. 7, no. 2, p. 22, 2018.
[3] H. S. Gandomani, S. M. yousefi, M. Aghajani et al., "Colorectal cancer in the world: incidence, mortality and risk factors," Biomedical Research and Therapy, vol. 4, no. 10, pp. 16561675, 2017.

[4] World Cancer Research Fund, Colorectal Cancer Statistics, World Cancer Research Fund, London, UK, 2018, https://www.wcrf.org/ dietandcancer/cancer-trends/colorectal-cancer-statistics.

[5] M. Arnold, M. S. Sierra, M. Laversanne, I. Soerjomataram, A. Jemal, and F. Bray, "Global patterns and trends in colorectal cancer incidence and mortality," Gut, vol. 66, no. 4, pp. 683-691, 2017.

[6] M. S. Pino and D. C. Chung, "The chromosomal instability pathway in colon cancer," Gastroenterology, vol. 138, no. 6, pp. 2059-2072, 2010.

[7] G. Aviello, B. Romano, F. Borrelli et al., "Chemopreventive effect of the non-psychotropic phytocannabinoid cannabidiol on experimental colon cancer," Journal of Molecular Medicine, vol. 90, no. 8, pp. 925-934, 2012.

[8] B. Romano, F. Borrelli, E. Pagano, M. G. Cascio, R. G. Pertwee, and A. A. Izzo, "Inhibition of colon carcinogenesis by a standardized cannabis sativa extract with high content of cannabidiol," Phytomedicine, vol. 21, no. 5, pp. 631-639, 2014.

[9] M. P. Davis, "Cannabinoids for symptom management and cancer therapy: the evidence," Journal of the National Comprehensive Cancer Network, vol. 14, no. 7, pp. 915-922, 2016.

[10] A. I. Fraguas-Sánchez, A. Fernández-Carballido, and A. I. Torres-Suárez, "Phyto-, endo- and synthetic cannabinoids: promising chemotherapeutic agents in the treatment of breast and prostate carcinomas," Expert Opinion on Investigational Drugs, vol. 25, no. 11, pp. 1311-1323, 2016.

[11] G. Velasco, C. Sánchez, and M. Guzmán, "Anticancer mechanisms of cannabinoids," Current Oncology, vol. 23, no. 2, pp. 23-32, 2016.

[12] E. Orrego-González, A Velez-Van-Meerbeke, and A. ValenciaCardenas, "Cannabinoids can induce tumor reduction on experimental colorectal cancer models: a systematic review," 2019, https://www.crd.york.ac.uk/PROSPERO/display_record. php?RecordID $=148356$.

[13] A. Liberati, D. G. Altman, J. Tetzlaff et al., "The prisma statement for reporting systematic reviews and meta-analyses of studies that evaluate health care interventions: explanation and elaboration," PLoS Medicine, vol. 6, no. 7, Article ID e1000100, 2009.

[14] C. R. Hooijmans, M. M. Rovers, R. B. de Vries, M. Leenaars, M. Ritskes-Hoitinga, and M. W. Langendam, "Syrcle's risk of bias tool for animal studies," BMC Medical Research Methodology, vol. 14, no. 1, p. 43, 2014.

[15] N. Battista, M. Di Tommaso, M. Bari, and M. Maccarrone, "The endocannabinoid system: an overview," Frontiers in Behavioral Neuroscience, vol. 6, 2012.

[16] S Zou and U Kumar, "Cannabinoid receptors and the endocannabinoid system: signaling and function in the central nervous system," International Journal of Molecular Sciences, vol. 19, no. 3, 2018.

[17] P. Morales, P. H. Reggio, and N. Jagerovic, “An overview on medicinal chemistry of synthetic and natural derivatives of cannabidiol," Frontiers in Pharmacology, vol. 8, 2017.

[18] R. Schicho and M. Storr, "Alternative targets within the endocannabinoid system for future treatment of gastrointestinal diseases," Canadian Journal of Gastroenterology, vol. 25, no. 7, pp. 377-383, 2011.

[19] V. Di Marzo, "The endocannabinoid system: its general strategy of action, tools for its pharmacological manipulation 
and potential therapeutic exploitation," Pharmacological Research, vol. 60, no. 2, pp. 77-84, 2009.

[20] C. Prandi, M. Blangetti, D. Namdar, and H. Koltai, "Structureactivity relationship of cannabis derived compounds for the treatment of neuronal activity-related diseases," Molecules, vol. 23, no. 7, p. 1526, 2018.

[21] B. Basavarajappa, "Neuropharmacology of the endocannabinoid signaling system-molecular mechanisms, biological actions and synaptic plasticity," Current Neuropharmacology, vol. 5, no. 2, pp. 81-97, 2007.

[22] R. Ramer, R. Schwarz, and B. Hinz, "Modulation of the endocannabinoid system as a potential anticancer strategy," Frontiers in Pharmacology, vol. 10, p. 430, 2019.

[23] J. A. Uranga, G. Vera, and R. Abalo, "Cannabinoid pharmacology and therapy in gut disorders," Biochemical Pharmacology, vol. 157, pp. 134-147, 2018.

[24] C. Muller, P. Morales, and P. H. Reggio, "Cannabinoid ligands targeting TRP channels," Frontiers in Molecular Neuroscience, vol. 11, p. 487, 2018.

[25] R. Piñeiro, T. Maffucci, and M. Falasca, "The putative cannabinoid receptor GPR55 defines a novel autocrine loop in cancer cell proliferation," Oncogene, vol. 30, no. 2, pp. 142152, 2011.

[26] R. A. Ross, "L- $\alpha$-Lysophosphatidylinositol meets GPR55: a deadly relationship," Trends in Pharmacological Sciences, vol. 32, no. 5, pp. 265-269, 2011.

[27] C. Andradas, M. M. Caffarel, E. Pérez-Gómez et al., “The orphan G protein-coupled receptor GPR55 promotes cancer cell proliferation via ERK," Oncogene, vol. 30, no. 2, pp. 245-252, 2011.

[28] J. Kargl, J. Haybaeck, A. Stančić et al., "O-1602, an atypical cannabinoid, inhibits tumor growth in colitis-associated colon cancer through multiple mechanisms," Journal of $\mathrm{Mo}$ lecular Medicine, vol. 91, no. 4, pp. 449-458, 2013.

[29] C. L. Bandet, S. Tan-Chen, O. Bourron, H. L. Stunff, and E. Hajduch, "Sphingolipid metabolism: new insight into ceramide-induced lipotoxicity in muscle cells," International Journal of Molecular Sciences, vol. 20, no. 3, p. 479, 2019.

[30] K. Gustafsson, B. Christensson, B. Sander, and J. Flygare, "Cannabinoid receptor-mediated apoptosis induced byR(+)methanandamide and win55,212-2 is associated with ceramide accumulation and p38 activation in mantle cell lymphoma," Molecular Pharmacology, vol. 70, no. 5, pp. 1612-1620, 2006.

[31] K. Gustafsson, B. Sander, J. Bielawski, Y. A. Hannun, and J. Flygare, "Potentiation of cannabinoid-induced cytotoxicity in mantle cell lymphoma through modulation of ceramide metabolism," Molecular Cancer Research, vol. 7, no. 7, pp. 1086-1098, 2009.

[32] C Sánchez, M. L de Ceballos, T Gomez del Pulgar et al., "Inhibition of glioma growth in vivo by selective activation of the $\mathrm{CB}(2)$ cannabinoid receptor," Cancer Research, vol. 61, no. 15 , pp. 5784-5789, 2001.

[33] R. Ramer, U. Weinzierl, B. Schwind, K. Brune, and B. Hinz, "Ceramide is involved in $\mathrm{r}(+)$-methanandamide-induced cyclooxygenase-2 expression in human neuroglioma cells," Molecular Pharmacology, vol. 64, no. 5, pp. 1189-1198, 2003.

[34] A. Greenhough, H. A. Patsos, A. C. Williams, and C. Paraskeva, "The cannabinoid $\delta 9$-tetrahydrocannabinol inhibits RAS-MAPK and PI3K-AKT survival signalling and induces BAD-mediated apoptosis in colorectal cancer cells," International Journal of Cancer, vol. 121, no. 10, pp. 21722180, 2007.
[35] A. A. Izzo, G Aviello, G. Aviello et al., "Increased endocannabinoid levels reduce the development of precancerous lesions in the mouse colon," Journal of Molecular Medicine, vol. 86, no. 1, pp. 89-98, 2008.

[36] S. B. Gustafsson, R. Palmqvist, M. L. Henriksson et al., "High tumour cannabinoid CB1 receptor immunoreactivity negatively impacts disease-specific survival in stage II microsatellite stable colorectal cancer," PLoS ONE, vol. 6, no. 8, Article ID e23003, 2011.

[37] J. Joseph, B. Niggemann, K. Zaenker, and F. Entschladen, "Anandamide is an endogenous inhibitor for the migration of tumor cells and T lymphocytes," Cancer Immunology, Immunotherapy, vol. 53, no. 8, pp. 723-728, 2004.

[38] F. Borrelli, E. Pagano, B. Romano et al., "Colon carcinogenesis is inhibited by the TRPM8 antagonist cannabigerol, a Cannabis-derived non-psychotropic cannabinoid," Carcinogenesis, vol. 35, no. 12, pp. 2787-2797, 2014.

[39] F. Cianchi, L. Papucci, N. Schiavone et al., "Cannabinoid receptor activation induces apoptosis through tumor necrosis factor -mediated ceramide de novo synthesis in colon cancer cells," Clinical Cancer Research, vol. 14, no. 23, pp. 7691-7700, 2008.

[40] A. Ligresti, T. Bisogno, I. Matias et al., "Possible endocannabinoid control of colorectal cancer growth," Gastroenterology, vol. 125, no. 3, pp. 677-687, 2003.

[41] L. Chen, H. Chen, Y. Li, L. Li, Y. Qiu, and J. Ren, "Endocannabinoid and ceramide levels are altered in patients with colorectal cancer," Oncology Reports, vol. 34, no. 1, pp. 447-454, 2015.

[42] D. Thapa, D. Babu, M.-A. Park et al., "Induction of p53independent apoptosis by a novel synthetic hexahydrocannabinol analog is mediated via Sp1-dependent NSAID-activated gene-1 in colon cancer cells," Biochemical Pharmacology, vol. 80, no. 1, pp. 62-71, 2010.

[43] Y. Moon, "NSAID-activated gene 1 and its implications for mucosal integrity and intervention beyond NSAIDs," Pharmacological Research, vol. 121, pp. 122-128, 2017.

[44] O. Pellerito, A. Notaro, S. Sabella et al., "WIN induces apoptotic cell death in human colon cancer cells through a block of autophagic flux dependent on PPAR $\gamma$ down-regulation," Apoptosis, vol. 19, no. 6, pp. 1029-1042, 2014.

[45] G. Velasco, I. Galve-Roperh, C. Sánchez, C. Blázquez, A. Haro, and M. Guzmán, "Cannabinoids and ceramide: two lipids acting hand-by-hand," Life Sciences, vol. 77, no. 14, pp. 1723-1731, 2005.

[46] S. Elmore, "Apoptosis: a review of programmed cell death," Toxicologic Pathology, vol. 35, no. 4, pp. 495-516, 2007.

[47] D. Wang and R. N. Dubois, "The role of COX-2 in intestinal inflammation and colorectal cancer," Oncogene, vol. 29, no. 6, pp. 781-788, 2010.

[48] M. Rahman, K. Selvarajan, M. R. Hasan et al., "Inhibition of COX-2 in colon cancer modulates tumor growth and MDR-1 expression to enhance tumor regression in therapy-refractory cancers in vivo," Neoplasia, vol. 14, no. 7, pp. 624-IN18, 2012.

[49] H. A Patsos, A Greenhough, D. J Hicks et al., "The endogenous cannabinoid, anandamide, induces COX-2-dependent cell death in apoptosis-resistant colon cancer cells," International Journal of Oncology, vol. 37, no. 1, pp. 187-193, 2010.

[50] D. Fiore, P. Ramesh, M. C. Proto et al., "Rimonabant kills colon cancer stem cells without inducing toxicity in normal colon organoids," Frontiers in Pharmacology, vol. 8, p. 949, 2017.

[51] M. C. Proto, D. Fiore, C. Piscopo et al., "Inhibition of Wnt/ $\beta$-Catenin pathway and Histone acetyltransferase activity by 
Rimonabant: a therapeutic target for colon cancer," Scientific Reports, vol. 7, no. 1, p. 11678, 2017.

[52] P Gazzerro, A. M Malfitano, M. C Proto et al., "Synergistic inhibition of human colon cancer cell growth by the cannabinoid CB1 receptor antagonist rimonabant and oxaliplatin," Oncology Reports, vol. 23, no. 1, pp. 171-175, 2010.

[53] S. B. Gustafsson, T. Lindgren, M. Jonsson, and S. O. P. Jacobsson, "Cannabinoid receptor-independent cytotoxic effects of cannabinoids in human colorectal carcinoma cells: synergism with 5-fluorouracil," Cancer Chemotherapy and Pharmacology, vol. 63, no. 4, pp. 691-701, 2009.

[54] M. Notarnicola, C. Messa, A. Orlando et al., "Estrogenic induction of cannabinoid CB1 receptor in human colon cancer cell lines," Scandinavian Journal of Gastroenterology, vol. 43, no. 1, pp. 66-72, 2008.

[55] E. Martínez-Martínez, I. Gómez, P. Martín et al., "Cannabinoids receptor type 2, CB2, expression correlates with human colon cancer progression and predicts patient survival," Oncoscience, vol. 2, no. 2, pp. 131-141, 2015.

[56] E. Pagano, F. Borrelli, P. Orlando et al., "Pharmacological inhibition of MAGL attenuates experimental colon carcinogenesis," Pharmacological Research, vol. 119, pp. 227-236, 2017.

[57] A. Santoro, S. Pisanti, C. Grimaldi et al., "Rimonabant inhibits human colon cancer cell growth and reduces the formation of precancerous lesions in the mouse colon," International Journal of Cancer, vol. 125, no. 5, pp. 996-1003, 2009.

[58] D. Thapa, Y. Kang, P.-H. Park et al., "Anti-tumor activity of the novel hexahydrocannabinol analog LYR-8 in human colorectal tumor xenograft is mediated through the inhibition of akt and hypoxia-inducible factor-1 $\alpha$ activation," Biological and Pharmaceutical Bulletin, vol. 35, no. 6, pp. 924-932, 2012.

[59] J. D. Orth, A. Loewer, G. Lahav, and T. J. Mitchison, "Prolonged mitotic arrest triggers partial activation of apoptosis, resulting in DNA damage and p53 induction," Molecular Biology of the Cell, vol. 23, no. 4, pp. 567-576, 2012.

[60] G. Sethi, B Sung, and B. B Aggarwal, “TNF: a master switch for inflammation to cancer," Frontiers in Bioscience, vol. Volume, no. 13, pp. 5094-5107, 2008.

[61] M. S. Hayden and S. Ghosh, "Regulation of NF- $\kappa$ B by TNF family cytokines," Seminars in Immunology, vol. 26, no. 3, pp. 253-266, 2014.

[62] J. A. DiDonato, F. Mercurio, and M. Karin, "NF- $\kappa$ B and the link between inflammation and cancer," Immunological Reviews, vol. 246, no. 1, pp. 379-400, 2012.

[63] H. Yu, D. Pardoll, and R. Jove, "STATs in cancer inflammation and immunity: a leading role for STAT3," Nature Reviews Cancer, vol. 9, no. 11, pp. 798-809, 2009.

[64] S. J Alrawi, M Schiff, R. E Carroll et al., "Aberrant crypt foci," Anticancer Research, vol. 26, no. 1A, pp. 107-119, 2006.

[65] J. van Meerloo, G. J. L. Kaspers, and J. Cloos, "Cell sensitivity assays: the MTT assay," Methods in Molecular Biology, vol. 731, pp. 237-245, 2011.

[66] J. Xiao, Z. Cai, W. Li et al., "Tumor volume reduction rate predicts pathologic tumor response of locally advanced rectal cancer treated with neoadjuvant chemotherapy alone: results from a prospective trial," Journal of Cancer, vol. 6, no. 7, pp. 636-642, 2015.

[67] N. Nishida, H. Yano, T. Nishida, T. Kamura, and M. Kojiro, "Angiogenesis in cancer," Vascular Health and Risk Management, vol. 2, no. 3, pp. 213-219, 2006.

[68] V. R. Adams, "Evolving role of antineoplastic agents in colorectal cancer," American Journal of Health-System Pharmacy, vol. 63, no. 9, pp. S4-S11, 2006.
[69] M. S. Braun and M. T. Seymour, "Balancing the efficacy and toxicity of chemotherapy in colorectal cancer," Therapeutic Advances in Medical Oncology, vol. 3, no. 1, pp. 43-52, 2011.

[70] F. G. A. Jansman, M. J. Postma, and J. R. B. J. Brouwers, "Cost considerations in the treatment of colorectal cancer," Pharmacoeconomics, vol. 25, no. 7, pp. 537-562, 2007. 